\title{
Speed of Adjustment in Dividend Payout Decisions: A Comparative Analysis of Developed and Developing Countries
}

\author{
Nicos Koussis \\ PhD, Assistant Professor of Finance \\ ORCID \\ Email: bus.kn@frederick.ac.cy \\ Frederic University, Nicosia, Cyprus
}

Vladislav Ruzinskii

Consultant

ORCID

Email: vladruz13@gmail.com

Baker Tilly in Russia, Moscow, Russia

Journal of Corporate Finance Research, Vol. 13, No. 2, pp. 7-24 (2019)

DOI: https://doi.org/10.17323/j.jcfr.2073-0438.13.2.2019.7-24

Received 15 April 2019 | Peer-reviewed 10 May 2019 | Accepted 3 June 2019

The journal is an open access journal which means that everybody can read, download, copy, distribute, print, search, or link to the full texts of these articles in accordance with CC Licence type: Attribution 4.0 International (CC BY 4.0 http://creativecommons.org/licenses/by/4.0/). 


\section{Speed of Adjustment in Dividend Payout Decisions: A Comparative Analysis of Developed and Developing Countries}

\section{Abstract}

This study examines the phenomenon of dividend smoothing, which is a policy of setting higher or lower dividend values than aligns with the levels of a company's earnings. Herein we specifically examine the speed of adjustment as a measure for the presence of dividend smoothing, and investigate how this manifests as a corollary to the phenomenon. Our research also includes an investigation of firms' internal characteristics and other relevant parameters which determine the speed of adjustment.

We perform an analysis on an international sample comprising more than 4000 non-financial companies from 40 countries. The data for analysis were obtained from the Capital IQ database. We identified relevant and pertinent variables based on a thorough analysis of the existing academic literature, and applied a series of analytical models based on Lintner's model for evaluating corporate dividend policy. We applied a number of modifications to Lintner's basic model which were tailored to suit our individual approach.

Our results illustrate the ubiquitous presence of dividend smoothing across our international sample, and indicates a general speed of adjustment equal to $64.8 \%$. Further, our results indicate that the speed of adjustment to a higher dividend level is significantly lower in comparison to the speed of adjustment to a lower dividend level. These differences in the speed of adjustment allows us to assert that the speed of adjustment in a group of companies which indicate a dividend fall of lower than 25\%, significantly differs from the case presented in the rest of the sample. In fact, the speed of adjustment in a group with a dividend fall lower than $25 \%$ is approximately equal to $100 \%$, while the remaining sample shows a speed of adjustment equal to $37 \%$.

Our results allow for us to present a single novel theory of dividend smoothing. We conclude that the speed of adjustment can be best explained from the perspective of the theory of information asymmetry. This conforms with the majority opinion from existing studies in the field. This paper uses the most recent data available and provides insights not previously established, which is especially interesting considering the international context of our sample. Our analysis provides ground for further investigation into the most salient results confirmed by our analysis, and most specifically, the question as to why is there a difference in the speed of adjustment between lower and higher levels of dividends.

Keywords: speed of adjustment, dividend payout, developing countries

JEL-classification: G32, G35 


\section{Introduction}

The analysis of dividends payout policy has been a popular subject of research since the middle of the 20th century. Despite a huge number of investigations there is no consensus opinion as to the best practices in the field. Over the years, different hypotheses have been put forward proposing various methodologies. Some working papers underline share repurchase as the best approach towards payout policy [1]. On the other hand, there are some investigations which emphasize the opposite point of view: that dividends are more preferable [2]. Another explanation states that there is no qualifiable difference in types of payout policy [3]. However, the majority of recent working papers argue that the best approach is to combine share repurchases and dividends [4].

Academic investigations into payout policy began with Lintner's working paper [5]. This research includes not only financial modeling and results based on regression analysis, but also presents information concerning the preferences of top-management in payout policy decisions. As a result of interviews with top managers, Lintner identified the existence of a target value for dividend payouts. So, managers tried to maintain the share of net income attributed to dividends instead of the value of dividends themselves. Moreover, Lintner found that there is a pertinent speed of adjustment ${ }^{1}$ in dividend policy. This phenomenon is described by the fact that in case of significant net income changes, firms do not pay all the dividends targeted at a specific level of net income. Companies only adjust the level of dividends in the direction of the changes. Lintner also provided an explanation of this fact. It was noted that companies' top management was sure that significant changes in dividends can be negatively appraised by the stock market, especially in case of a fall in the value of dividends. So, managers understate the changes in dividends to better assure that next year's profit can cover the new dividends. However, next year's net income also incurs some fluctuations, so it it is necessary to make some adjustments to dividends. As a result the process of dividend adjustment becomes permanent.

The investigation of Brav et al. [6] also was devoted to the analysis of payout policy, and included interviews with a large number of CFOs. This research confirms the main results of Lintner's work, but with some limitations. The study carefully analyzed the existence of any target level in payout decisions. The authors found that only $6 \%$ of CFOs do not target dividends at all. However, in contrast to Lintner's work the majority of CFOs (approximately 40\%) answer that their key target is dividends per share. Only $28 \%$ try to target a dividends payout, and $27 \%$ of managers target dividends per share growth. This investigation shows that nowadays, targeting dividends per share is a more common practice than targeting payouts. Despite the fact that these results display some differences from Lintner's one, they do not reject the hypothesis about existence of dividend smoothing.

\section{Relevance and academic novelty}

The question of academic novelty also attracts a lot of attention due to the fact that the payout policy was carefully analyzed in many studies during a period of more than half a century. First of all, the majority of investigations on this topic are devoted to the determination of a speed of adjustment for a particular country [7-11]. In the studies connected to this question, the determination of the underlying characteristics that drive the speed of adjustment was not treated with priority. Our work will address this problem. In addition, an up-to-date sample will be utilized in this investigation, so, the most recent data will be analyzed.

However, the main feature of this working paper, which emphasizes its novelty, is our analysis of difference in the speed of adjustment. This work sets the task of investigation of the speed of adjustment in two cases: where there are increases and where there are decreases in dividend payments. Despite similar reasons for the smoothing of dividends in these two cases, the decision-making mechanism of management is slightly different.

For the first case (increase in dividends), we will discuss the question of the speed of adjustment to a higher level of dividends. It will be associated with higher profits in the current period. On the contrary, the second case (decrease in dividends) will illustrate the mechanism of dividend smoothing in the situation of a fall in profits in the current period.

In the case of an increase in dividends, the firm generates more profit in comparison with the previous period. The company's management assumes that it could represent a one-time growth of earnings and the firm may obtain less profit over the subsequent period. In such a case, if the management team decides to keep the payout rate constant, the firm should increase dividends in the current period and decrease them going forward. However, as was shown in numerous investigations $[5,6]$, the majority of managers are certain about the possibility of a negative market reaction to dividend cuts. So, in the first case, management prefers to pay only part of a target dividend. In subsequent years, the confidence of a management team will grow and they will adjust dividends. However, the company's profit is non-constant and it differs from year to year, and that is why the process of dividend smoothing is a permanent phenomenon.

In the second case, in comparison with the first one, the company decreases the dividend. If it is assumed (as it was in the first case) that management decides to keep the payout rate constant, the firm should decrease dividends in predetermined proportions. However, as is tested

\footnotetext{
${ }^{1}$ The speed of adjustment is a commonly used measure of dividend smoothing. It shows how fast the target payout ratio is adjusted in relation to the changes in a firm's earnings. The faster the target payout ratio is adjusted, the lower the degree of smoothing.
} 
and analyzed in this investigation, it may be postulated that in assuming the negative effect of a dividend cut, a firm's management generally prefers to reduce the fall of dividends. This hypothesis seems to be reasonable due to the fact that some managers even take on debt in order to pay dividends [12]. So, the model of analyzing dividend smoothing is also applicable in the case of dividend cuts.

Despite very similar reasons for dividend smoothing, the mechanism of management decision-making about dividend payment differs in the two cases presented above. Due to this difference the following question arises: is the speed of adjustment in cases of dividend growth equal to speed of adjustment in case of dividend cut or not? This particular investigation will be a key point in novelty of this working paper.

Summarizing the above, the main points of economic novelty are:

- A single theory concerning dividend smoothing is developed.

- The company characteristics which drive the speed of adjustment are investigated.

- An analysis of differences in the speed of adjustment between lower and higher dividend levels is provided.

\section{Literature review}

\section{The position of dividend smoothing in investigations}

As was mentioned above, the results concerning target dividend levels were obtained by interviewing the companies' CFOs. Decisions regarding dividend smoothing were driven by their opinions, so the motivation of managers should be explained. The explanation of the CFOs' motivation can be taken from the book written by J. Tirole "The Theory of Corporate Finance" [13, pp. 311-314]. The J. Tirole's model assumes that there is information asymmetry between managers and shareholders (including potential shareholders) and companies' dividends are the signal of managers' productivity. The author took the model of income smoothing created by Fudenberg and Tirole in 1995, and modified it with the addition of dividends. The initial model shows that there are two periods: in the first, the firm obtains some profit and managers report the profit of first year In the second, the firm again obtains a profit, and then there is a comprehensive audit, which can carefully estimate the profit for previous periods. However, management can hide some profit from the first period to increase the profit of the second period by this amount. The reason for doing this is that the decrease in the second period's profit can be regarded as a loss of manager's efficiency and in such cases the manager will be fired. The decision to hide the first period's profit also can be explained by the uncertainty about the second period's profit. This model also can be applied for dividends. With regard to payout policy, the CFO can decrease dividends in the first period, so the dividends at the second period will be higher. Applying this model to dividends, it is assumed that a decrease in dividends will be represented as an indicator of a decline in managers' productivity. As can be seen, the majority of firms have no constant level of profit, but as mentioned above, try to maintain the same level of dividend. So, the presence of the two factors of volatile profitability and a relatively constant level of dividends leads to the phenomenon of permanent dividend smoothing, which means companies partly adjust their dividends every period with some SOA.

In some cases, the chosen payout policy imposes restrictions on managers' work. So, the maintaining of target levels of dividends can solve the agency conflict $[14,15]$. The existence of such a target level can motivate managers to choose the most profitable and reject the most risky projects in order to generate the required amount of net income. However, the investigation of Brav et al. [6] showed that the majority of executives (approximately $87 \%$ ) do not observe a relationship between payout policy and discipline imposed by dividends. It should be mentioned that share repurchase levels are also not attributed to self discipline measures. There is another important factor at play concerning share repurchases. The investigation [6] described how dividends and share repurchases are not considered as substitutes by CFOs. It is well known that decisions about dividends are made simultaneously with investment decisions. According to the interview in question, funds allocated for share repurchases are planned after the decision has been made about dividends and investment.

However, the principal-agent models are not the only explanations for dividends smoothing. There are some other reasons for such phenomena, one of them being the effect of external financing constraints [16]. According to this theory, companies involved in dividends smoothing can have problems with external financing. In such cases, firms tend to smooth dividends, because the profit of future periods can be insufficient to cover both investment opportunities and prior levels of dividends. It should be emphasized that the firms will smooth dividends in such cases precisely because of their inability to finance investments by using external funds, so they resort to a more flexible payout policy.

In contrast to the explanation presented by Bates et al. DeAngelo and DeAngelo [17] showed that the phenomenon of dividends smoothing can be common for firms even without external financing constraints. Their investigation illustrates the advantages of low leverage, because of the presence of financial flexibility and the availability of low-cost external capital. The research also illustrates how in such cases leverage will not be an appropriate instrument for solving the agency conflict problem. Therefore, the best strategy will be low leverage and high equity payouts with a high level of dividends smoothing to solve the agency problems.

Another explanation for smoothing refers to the clientele theory in general and to information asymmetry among investors [18]. The less informed individual investors will 
prefer dividends to decrease their information disadvantage in comparison with institutional investors. So, in case of a firm's hold by individual investors, the dividends will be smoothed more and all earnings fluctuations will be paid in the form of share repurchases. It was mentioned above that dividends, as a rule, become a positive signal for markets. The theory of dividends smoothing can expand this signaling role. It can be seen that the theory assumes that firms tend to increase their dividends (if they smooth it) only in cases where they are certain of future earnings. So, an increase in dividends where the company smoothes it should be a good signal of managers' confidence in a permanent growth of net income [19]. For a confirmation of the signaling point of view, the investigation of Grullon et al. [1] is of interest. The results illustrated in this working paper show that an increase in the dividend level of $10 \%$ is associated with a share price growth of $1.34 \%$, and a decrease in dividend level of $10 \%$ is associated with a fall in share prices of $3.71 \%$. There is another important feature here. It can be seen that the stock market reacts differently to a growth and a fall in dividends. Such phenomena should be reflected in different degrees of dividends smoothing, and in different speeds of adjustment for different directions of changes.

The importance of signaling theory for share repurchases is much more questionable. First of all, it should be mentioned that dividends are paid on a regular basis, while buy backs occur irregularly. Therefore, there is less evidence to indicate its speed of adjustment. This argument of irregularity also was used by Skinner [20]. On the other hand, there are lots of theories describing the signaling role of repurchases. The majority of them are based on the fact of information asymmetry between managers and other market participants. According to a number of articles, managers can use the signaling factor of repurchases to manipulate the stock price. So, there is confirmation that if the shares are overpriced the company tends to issue new stocks [21]. Similarly, if managers suppose that shares are underpriced they can give this signal to the stock market by providing buy backs [19]. In such cases share repurchases and the issue of new stock provide the same signals as dividends changes.

Since the Lintner investigation, several working papers analyzing payout policy have been published. Some of them, as was shown above, tested the applicability of Lintner's suggestions, some of them studied the speed of adjustment across countries, and a third group tried to investigate the factors determining it. This section will be devoted to the analysis of the second group of works. First, it is necessary to present Lintner's original results. Lintner estimated that the average payout among firms is equal to $52 \%$ and the speed of adjustment is equal to 0.32 . The estimation of speed of adjustment can explain the planning horizon of firms. It is assumed that a high speed of adjustment is common for firms with a short planning horizon (the converse is also true).
However, nowadays many studies show the decreasing importance of dividends. Fama and French [22] named it "disappearing dividends" because firms that pay dividends have decreased in numbers during the past decades. Simultaneously, with the decrease of number of companies which pay dividends, there is a downward trend in dividends payouts on the US market (in comparison with Lintner's time). By contrast, there is strong evidence of the expanding role of share repurchases. It should be mentioned that its increase is common for firms not only in US, but in other countries as well [23].

Summarizing the above, there is no clear understanding of the phenomenon of dividend smoothing. Previous investigations have controversial results on the question of the influence of a firm's characteristics. Moreover, there are a selection of articles which propose different arguments for the impact of determinants.

Currently, there are very few studies analyzing the comparison of adjustment rates to a higher and lower dividend level.

\section{Determinants of speed of adjustment}

It is necessary in our study to outline and describe the individual determinants which can explain the speed of adjustment. In fact, there are no common or standard explanatory variables for the speed of adjustment. A huge number of variables are included in dividends smoothing analyses. Here, the main determinants will be covered, the impact of which was confirmed through empirical investigations. The explanation of their impact is based on three theories: information asymmetry, agency problems and investor clientele. Sometimes, these theories give different interpretation and even impact on speed of adjustment. The results of previous investigations are presented in the appendix (Table 12).

\section{Firm maturity}

The determinant of firm maturity is the size of the firm. The size is equal to the natural logarithm of a company's assets [24]. The reason for the choice of the firms' maturity characteristic is that more mature firms experience less information asymmetry, since they are better known for all market participants. As was explained above, low information asymmetry is associated with a higher speed of adjustment, so the correlation between firm maturity and the speed of adjustment is expected to be positive.

\section{Growth opportunities}

There are some different approaches towards estimating growth opportunities, but the majority of articles include the market-to-book ratio $^{2}$ as the measure. It is clear that growth opportunities tend to be much easier determined by managers of a company in comparison with outside market participants. Therefore, the higher the growth opportunities, the higher the information asymmetry should be, and as a result, the lower the speed of adjustment. 
On the other hand, Leary and Michaely [25] relied on agency problems and came to the conclusion that the relationship is positive. The authors assume that higher investment opportunities define the dividends, so such firms will pay less and smooth less. According to this theory, higher growth opportunities lead to a higher speed of adjustment. It seems to be clear that firms with higher growth opportunities tend to have fewer problems with the allocation of high free cash flows. The availability of good investment projects and low free cash leads to lower agency conflicts. In such cases, there is no need to restrict the role of dividends.

\section{Assets tangibility}

The explanation of the impact of assets tangibility ${ }^{3}$ seems to be the same as the impact of firm maturity. It is well known that firms with higher proportions of tangible assets have lower information asymmetry. Therefore, the dependence of the speed of adjustment on assets tangibility should be positive [25].

\section{Volatility of earnings}

The volatility of returns is another measure of information asymmetry. Firms with higher volatility of earnings always have a risk of obtaining low net income. In some cases, this base for dividends payout can be too low; therefore, these companies are reluctant to increase dividends and prefer to smooth it. Therefore, it can be seen that firms with high returns volatility have a lower speed of adjustment.

\section{Risk}

The returns volatility can be a proxy for company's risk measure as well as a measure of information asymmetry [25]. It is argued that a higher return volatility is connected with higher uncertainty, and as a result, with higher information asymmetry. We anticipate that risk negatively correlates with dividend smoothing and positively correlates with the speed of adjustment.

\section{Institutional holders}

The percentage of institutional holders also can be a good determinant for the speed of adjustment. From an information asymmetry point of view the relationship between institutional holders and the speed of adjustment should be positive. It can be explain by the fact that institutions are expected to lower information asymmetry between insiders and other participants due to their better skills in gathering information [26]. Moreover, they are usually involved in activism ${ }^{4}$, which also reduces the informational asymmetry [27]. Other research [25] points out that the dependence of dividends smoothing on institutional holdings should be negative, and therefore the correlation with the speed of adjustment is expected to be positive.
This argument is based on agency theory. According to this theory, institutional holders will lower agency costs due to their high negotiating power and corporate behavior. In such cases, companies will not smooth dividends to decrease the agency costs.

However, there is another point of view. According to Jeong [24], firms with a higher percentage of institutional investors tend to smooth dividends more, due to their tax advantage. So, according to the clientele theory, the relationship between the speed of adjustment and the percentage of institutional holders is predicted to be negative.

\section{Ownership concentration}

The ownership concentration is usually estimated as the number of shares held by the largest holders divided by all outstanding shares, but there are some variations in formulas. According to the majority of studies, the correlation between the speed of adjustment and ownership concentration is predicted to be positive from the agency point of view. Jeong [24] supposes that more closely held firms have less agency problems in comparison with dispersed ownership. In addition, large individual holders will have more negotiation power and higher ability of monitoring. Therefore, it should be forecast that companies with a higher concentration of ownership would not need to pay out and smooth as much as firms with dispersed ownership. Moreover, many companies which are held by several large investors are family firms (especially in developing markets). Such firms usually have a very low level of information asymmetry between managers and owners, so from this point of view the impact on the speed of adjustment should be positive.

\section{Investment horizon}

Some investigations [28] argue that the investment horizon of stockholders also can affect the managers' decision to smooth dividends. The investment horizon is a proxy of the stock turnover, which is estimated as the number of stocks traded in the year, divided by the quantity of all outstanding shares. The explanation of the impact of the high investment horizon is associated with lower information asymmetry and a higher speed of adjustment as a result. However, some other investigations [25] have found that correlation between the investment horizon of stockholders and the speed of adjustment tend to be insignificant.

\section{Hypotheses}

Hypothesis №1: Dividend smoothing is a pertinent phenomenon among public firms.

The phenomenon of dividend smoothing has been widely investigated in the literature $[5,8,9,28]$. However, some researchers underline the decreasing role of dividends [22]. The determination of dividend smoothing should also be a starting point in further analysis.

\footnotetext{
${ }^{3}$ PPE divided by total assets.

4 “Actions taken by shareholders with the explicit intention of influencing corporations' policies and practices" [11].
} 
Hypothesis №2: Internal firm characteristics have an influence on the speed of adjustment in dividend payout decisions.

Those investigations which focused on the determination of parameters driven by the speed of adjustment have had controversial results [24, 25, 28]. Moreover, some studies explain the impact of determinants according to different phenomena, e.g. information asymmetry, theory of clientele, agency theory [24-26, 28].

Hypothesis №3: The speed of adjustment to a higher level of dividends is lower in comparison with the speed of adjustment to lower level of dividends.

Research indicates that dividend cuts have a more significant impact than dividend increases [1]. Considering this point, it can be assumed that a dividend decrease is connected with the current problems of a firm. As a result of such current problems, the planning horizon is decreased and a firm adjusts its dividend level to the target level very fast.

By contrast, the decrease of dividends per share can be associated with an increase in the reinvestment rate. This increase can be a signal of growth in the planning horizon and leads to a fall in the speed of adjustment. This point can be supported by the theory of financial constraints [16], outlining the probability of complexity in the use of external financing. According to this theory, dividend smoothing in "good" years can be a driver of future growth due to a reinvestment of earnings. In addition, assuming that managers are reluctant to cut dividends [6], managers should more significantly smooth the falling value of dividends.

\section{Model's specification}

The next step of this work will be devoted to the specification of our analytical model. During the first stage, Lintner's model will be analyzed. The results of the first regression will be used to determine the speeds of adjustments. During the second step, the impact of determinants on the obtained speeds of the adjustments will be tested. Due to the model's specifications the first step allows for the use of panel data, but it cannot be done for the step of analyzing determinants of the speed of adjustment. The speed of adjustment will be obtained for a period of several years, which is why the idea of using panel data here is not applicable. This approach imposes additional limitations, the explanatory variables also should not have changes in time. Therefore, the most appropriate decision is to use median and average values for determinants [25]. First of all, the original Lintner's model should be presented.

$$
\begin{aligned}
& \Delta \mathrm{DPS}_{\mathrm{it}}=\mathrm{DPS}_{\mathrm{it}}-\mathrm{DPS}_{\mathrm{it}-1}= \\
& =\beta_{\text {เйบินข }}\left(\mathrm{DPS}^{*}-\mathrm{DPS}\right)+\varepsilon
\end{aligned}
$$

DPS $_{i t}$ refers to dividends per share of firm $i$ in year $t$. This model is widely used in the literature [20, 24, 25]. Some investigations propose to divide dividends by book value of assets in order to scale it [22]. However, as was mentioned above [6] the dividend per share is a key measure for payout policy, so the best decision to control the scale is to divide the dividends by the number of outstanding shares. DPS ${ }_{\text {it }}^{*}$ refers to a target dividend in the year $\mathrm{t}$. The formula for this target dividend is:

$\mathrm{DPS}_{\mathrm{it}}^{*}=$ payout $^{*} E P S_{i t}$, where payout is a target payout ratio and $E P S_{i t}$ is earnings in period t. The calculation of the speed of adjustment is based on an estimation of the coefficient $\hat{\gamma}$. However, this formula should have some adjustments for the determination of the coefficient. So, the revised formula is presented thusly: $\Delta \mathrm{DPS}_{\mathrm{it}}=\beta_{0}+\beta_{1} \mathrm{DPS}_{\mathrm{it}-1}+\beta_{2} \mathrm{EPS}_{\mathrm{it}}+\varepsilon_{\mathrm{it}}$, where $\beta_{2}=\gamma \cdot P$ ayout.

Of course, earnings in this regression are also controlled by scale. So, $E P S_{i t}$ is equal to earnings per share.

This model's specification was widely used in many investigations, including Lintner's one, but in this case it raises some questions. It can be seen that the target payout ratio and speed of adjustment are determined by the regression, and by obtaining the coefficients. This leads to the fact that the speed of adjustment in such cases is just a coefficient, so this model specification does not allow for the analyzing of determinants of the speed of adjustment. So, another method to determine the speed of adjustment should be chosen.

The alternative method to Lintner's model is the use of a two-step procedure. In this case our results will be better, and it allows us to obtain the desired series of values of speeds of adjustment [25]. During the first step, the regressions presented above are built for each company, which allow us to obtain the vector of beta (the number of betas is equal to number of companies in the sample). During the second step the vector of SOA (speed of adjustment) is obtained (SOA for each company is equal to the beta determined in the regression multiplied by -1 ). The last step will be devoted to estimating the coefficients in the regression (table 1):

$\mathrm{SOA}_{\mathrm{i}}=\alpha_{0}+\sum_{\mathrm{i}=1}^{\mathrm{n}} \alpha_{t} \mathrm{Z}_{t}+\mu_{t}$

where $\mathrm{Z}_{\mathrm{i}}$ is the vector of determinants.

Table 1. Explanatory variables in model 3

Explanatory variables $\left(\mathrm{Z}_{\mathrm{i}}\right)$

$\mathrm{MB}$ - the market value of equity plus the book value of assets minus the book value of equity, all divided by the book value of assets

Stock turnover - the annual average of the ratio of monthly traded volume of shares to total shares outstanding

Size - natural logarithm $\quad$ SD (EBIT) - the stanof total assets dard deviation of EBIT

Institutional ownership - SD (Price) - the average the percentage of shares standard deviation of held by institutions monthly stock returns 


\section{Explanatory variables $\left(\mathrm{Z}_{\mathrm{i}}\right)$}

Ownership concentration - percentage of common shares owned by largest shareholder ty, plant and equipment (PP\&E) scaled by total assets
Tangibility - net proper-

The majority of authors $[24,25,29]$ propose the use of median value of parameters during the observable period. The investigation presented above was conducted in some studies devoted to the analysis of payout policy. It should be mentioned that our current study includes up-to-date data and explanatory variables which were not carefully analyzed in previous research. However, the methodology of this investigation was used in some significant articles. So, the novelty of the current work will be described in more detail below.

The third step of the analysis will be devoted to the investigation of the difference in the speed of adjustment. First, the dummy variable will be generated:

$$
\mathrm{A}=\left\{\begin{array}{l}
1, \text { if } \Delta \mathrm{DPS}_{\mathrm{it}}<0 \\
0, \text { if } \Delta \mathrm{DPS}_{\mathrm{it}} \geq 0 .
\end{array}\right.
$$

The inclusion of the dummy variable allows for the identification of the difference in the speed of adjustment to lower dividend levels and to higher dividend levels. The reason for applying such a parameter is as follows: previous studies investigated and compared the effects of an increase and decrease of dividends on share price [1]. The current study allows for the identification of the difference in the speed of adjustment.

The new model is a modified Lintner's model with the inclusion of a dummy variable:

$$
\Delta \mathrm{DPS}_{\mathrm{it}}=\beta_{0}+\beta_{1} \mathrm{DPS}_{\mathrm{it}-1}+\beta_{2} \mathrm{EPS}_{\mathrm{it}}+\beta_{3} A_{i t}+\varepsilon_{\mathrm{it}} .
$$

However, the aim of using a dummy variable is much more significant. The inclusion in the model of a new variable equal to lagged DPS multiplied by dummy $A_{i t}$ allows not only for identifying the difference in the speed of adjustment, but also allows for the measuring of this difference:

$$
\begin{aligned}
& \Delta \mathrm{DPS}_{\mathrm{it}}=\beta_{0}+\beta_{1} \mathrm{DPS}_{\mathrm{it}-1}+\beta_{2} \mathrm{EPS}_{\mathrm{it}}+ \\
& +\beta_{3}\left(A_{i t} \cdot \mathrm{DPS}_{\mathrm{it}-1}\right)+\varepsilon_{\mathrm{it}} .
\end{aligned}
$$

As the new model is used, new values of SOA will be obtained. There is no difference in the speed of adjustment in the case of a dividends increase, because dummy $A_{i t}$ is equal to 0 in this case, so the $\mathrm{SOA}=-\beta_{1}$. On the other hand, the speed of adjustment in the case of a dividends cut will change, because dummy $\mathrm{A}$ is equal to 1 , so $\mathrm{SOA}=-\left(\beta_{1}+\beta_{3}\right)$. Summarizing the above, the following values of SOA are obtained:

$\mathrm{SOA}=\left\{\begin{array}{c}-\left(\beta_{1}+\beta_{3}\right), \text { if } \triangle D P S<0 \\ -\beta_{1}, \text { if } \triangle D P S \geq 0 .\end{array}\right.$
Another one important point to mention is that in this analysis the Arellano-Bond's method is used. Since in the model the dependent variable is dividend per share in year $t$ and the explanatory variable is dividend per share in year $t-1$ the random error has significant correlation with dividend per share in year $t-1$. In this case the parameters' estimations become inconsistent and the standard panel regression analysis is impossible.

The problem explained above could be solved with two methods: the method of instrumental variable, and the generalized method of moments (GMM). In this work the second method will be implemented. This method was carefully explained in the article written by Arellano and Bond in 1991 [30] and allows for making the estimations of the parameters consistent.

The last step of the model's specification is also devoted to the analyzing of the difference in the speed of adjustment. During this step, the indicative variable will be included instead of the dummy. This modification allows us to divide the sample by several groups depending on the changes in DPS in percentages and identifying the difference in the speed of adjustment between these groups. The obtained model is presented as follows:

\begin{tabular}{|c|c|}
\hline$\frac{\Delta \mathrm{DPS}_{\mathrm{it}}}{\mathrm{DPS}_{\mathrm{it}-1}}(\mathrm{X})$ & Factor variable (I) \\
\hline$X<-0.25$ & 1 \\
\hline$-0.25 \leq X<-0.1$ & 2 \\
\hline$-0.1 \leq \mathrm{X}<0$ & 3 \\
\hline$X=0$ & 4 \\
\hline $0<X \leq 0.08$ & 5 \\
\hline $0.08<X \leq 0.26$ & 6 \\
\hline $0.26<X$ & 7 \\
\hline
\end{tabular}

$$
\Delta \mathrm{DPS}_{\mathrm{it}}=\beta_{0}+\beta_{1} \mathrm{DPS}_{\mathrm{it}-1}+\beta_{2} \mathrm{EPS}_{\mathrm{it}}+\beta_{3} \mathrm{I}+\varepsilon_{\mathrm{it}},
$$

where I - indicator. (8)

Table 2. Factor variable composition

The ranges of factor variables are based on number of observations in each group (table 2). The number of observations in each group with positive changes of DPS is approximately equal. The same is true for group with negative changes of DPS.

Summarizing the above, the models include analysis of the speed of adjustment, parameters which determine speed of adjustment, and differences in the speed of adjustment in cases of dividends' growth and cut. It should be also mentioned that this investigation shows the difference in the speed of adjustment among the developed and emerging countries and among economic sectors. 
Table 3. Sample allocation by sectors

\begin{tabular}{|c|c|c|c|}
\hline Sector & Number of firms & Percentage & Cumulative \\
\hline Consumer discretionary & 917 & 19.7 & 19.7 \\
\hline Consumer staples & 491 & 10.55 & 30.25 \\
\hline Energy & 141 & 3.03 & 33.28 \\
\hline Healthcare & 244 & 5.24 & 38.52 \\
\hline Industrials & 1207 & 25.93 & 64.45 \\
\hline Information technology & 512 & 11 & 75.45 \\
\hline Materials & 580 & 12.46 & 87.91 \\
\hline Real estate & 358 & 7.69 & 95.6 \\
\hline Telecommunication services & 48 & 1.03 & 96.63 \\
\hline Utilities & 157 & 3.37 & 100 \\
\hline
\end{tabular}

Table 4. Results of regression (model 2)

\begin{tabular}{|c|c|c|c|}
\hline Variables & All countries & Developed & Emerging \\
\hline $\mathrm{DPS}_{\mathrm{it}-1}$ & $-0.648^{\star * *}$ & $-0.607^{\star * *}$ & $-0.99^{* * *}$ \\
\hline \multirow[t]{2}{*}{$\mathrm{EPS}_{\mathrm{it}}$} & $0.327^{\star * *}$ & $0.322^{\star * *}$ & $0.359^{* * *}$ \\
\hline & \multicolumn{3}{|c|}{$\mathrm{p}$-values are: ${ }^{\star *} \mathrm{p}<0.01,{ }^{\star *} \mathrm{p}<0.05,{ }^{\star} \mathrm{p}<0.1$} \\
\hline Tests & \multicolumn{3}{|c|}{ p-values } \\
\hline Sargan & 0.1620 & 0.3352 & 0.060 \\
\hline \multirow{3}{*}{ Arellano-Bond } & 0.0908 & 0.1857 & 0.2709 \\
\hline & 0.9206 & 0.8693 & 0.9459 \\
\hline & 0.5847 & 0.2381 & 0.0843 \\
\hline
\end{tabular}

\section{Data and sample selection}

The data for analysis were obtained from the Capital IQ database. Since the investigation was devoted to the payout policy it was required that each firm should have data about dividends payment available from 2007 to 2016 . Due to certain special requirements, financial firms were excluded from the sample. To carefully calculate the speed of adjustment only those firms with 10 years of continuous, non-missing data for earnings and dividends per share were included. It is also required for firms to have at least 5 years of available accounting data downloaded from the Capital IQ database. Since this work presents an international analysis of dividend smoothing, it was required for all countries to have at least 5 companies in the sample, so the other observations were excluded. As a result, the final sample consists of 4655 companies from 19 developed and 21 emerging countries.

Approximately three quarters of companies in the final sample are from developed countries. The most significant number of observations are from Japan (1373 companies), the United States (589 companies), and the United Kingdom (216 companies). Among the emerging countries India, China, and Malaysia have the most significant number of firms in the sample (201, 177, and 162 companies respectively). The allocation of companies by countries is presented in the appendix (Table 13).

The data also include information about the primary sectors of companies. The majority of firms in the final sample operate in the consumer discretionary sector and the industrial sector, while the telecommunication services sector is the smallest one. The allocation of companies according to 10 groups by sectors is presented below in the table 3.

The correlation matrix is presented in the appendix (Table 14). The matrix shows that probability of multicollinearity is rather low, but the variance inflation factor (VIF) will be calculated and presented as part of a robustness check. 
Table 5. Results of regression by sectors (model 2)

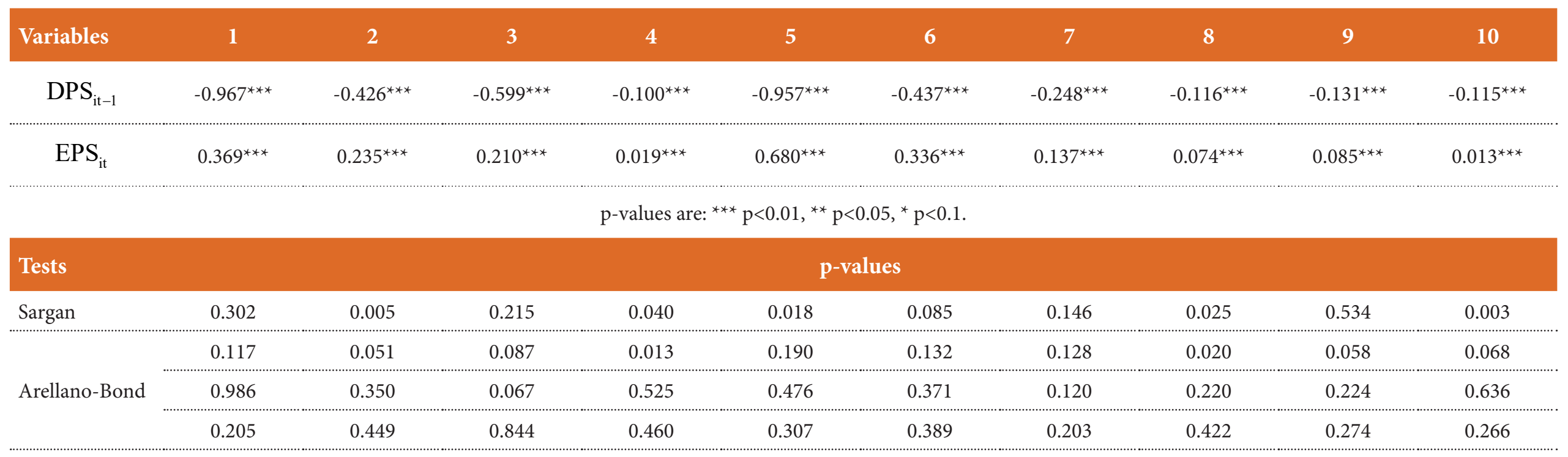
1 - Consumer Discretionary
2 - Consumer Staples
3 - Energy
4 - Healthcare
5 - Industrials
6 - Information Technology
7 - Materials
8 - Real Estate
9 - Telecommunication Services
10 - Utilities 
Table 6. Results of regression (model 6)

\begin{tabular}{|c|c|c|c|}
\hline Variables & All countries & Developed & Emerging \\
\hline DPS $_{i t-1}$ & $-0.598^{\star * *}$ & $-0.540^{\star * *}$ & $-0.241^{\star * *}$ \\
\hline $\mathrm{EPS}_{\mathrm{it}}$ & $0.310^{* * *}$ & $0.296^{* * *}$ & $0.319^{* * *}$ \\
\hline Dummy•DPS $\mathrm{PS}_{\mathrm{it}-1}$ & $-0.051^{\star * *}$ & $-0.054^{\star * *}$ & $-0.764^{* * *}$ \\
\hline \multicolumn{4}{|c|}{$\mathrm{p}$-values are: ${ }^{* *} \mathrm{p}<0.01,{ }^{* *} \mathrm{p}<0.05,{ }^{*} \mathrm{p}<0.1$} \\
\hline Tests & & p-values & \\
\hline Sargan & 0.410 & 0.740 & 0.000 \\
\hline \multirow{3}{*}{ Arellano-Bond } & 0.092 & 0.192 & 0.253 \\
\hline & 0.750 & 0.547 & 0.612 \\
\hline & 0.491 & 0.188 & 0.051 \\
\hline
\end{tabular}

\section{Empirical analysis}

\section{Lintner's model}

As was shown in the section on our model specifications, the first step will be devoted to the analysis of the standard Lintner's model. This step allows for the obtaining of an overall understanding of collected data and allows for the comparing of current results with previous results.

We showed above that in the data analysis, the generalized method of moments is more applicable. So, during the first step of the investigation the GMM was applied for the Lintner model. This part of the sample also was divided by two groups. In the first group, the companies from emerging countries were included, and in the second, developed countries were included.

First of all, the significance of parameters should be mentioned. All parameters are significant at a $1 \%$ level of significance. Moreover, all parameters have anticipated signs. The analysis of GMM also indicates that instruments are valid (with the exception of regression built on emerging countries) and there is no autocorrelation. All data presented above show that the parameters' estimations are consistent.

As can be seen from the table 4, the speed of adjustment for all companies in the sample is equal to $64.8 \%$. Approximately two thirds of the companies are from developed countries, so it is not surprising that overall SOA is closer to SOA of developed countries in comparison with emerging ones.

The speeds of adjustment of developed and emerging countries are $60.7 \%$ and $99 \%$ respectively. That means companies in developing countries adjust their dividends to the target level much faster. These results, indicating such differences in SOA between developed and emerging countries were also obtained in the majority of previous investigations [10, 28]. The higher speed of adjustment shows that companies in emerging countries have a very fast adjustment to dividend levels and very low dividend smoothing. This parameter indicates that only $1 \%$ of previous earnings were not reflected in dividends. It further indicates that firms in emerging countries have a significantly lower planning horizon.

During the analysis of Lintner's model, the sample was divided not only by developed and emerging countries but also by the primary sectors of companies. The results of this analysis are presented in the table 5 .

As can be seen from the table 6 , all parameters in the regressions are significant. The results also show that there is a difference in the speed of adjustment in different economic sectors. The highest values are in the consumer discretionary sector and in the industrial sector $(96.7 \%$ and $95.7 \%$ respectively). It is interesting that these two groups of companies are the biggest, which is why the overall sample has a rather high speed of adjustment (the speed of adjustment in the other eight groups is lower than in the overall sample).

The overall results show that dividend smoothing is the pertinent phenomenon among public firms. So, the first hypothesis can not be rejected.

\section{Lintner model with dummy variable}

The second step of the analysis is devoted to the modification of Lintner's model. As was previously explained, at the first stage a dummy variable will be added. The inclusion of the dummy variable allows for an analysis of the difference in the speed of adjustment to a lower dividend level in comparison with the speed of adjustment to a higher dividend level. The dummy variable included in 
the regression is equal to 1 if dividend per share of year $t$ is higher than dividend per share of the previous year, and equal to 0 otherwise.

However, the importance of a dummy variable will be more significant in the case of using a new variable equal to the dummy multiplied by the lagged dividend per share. This model allows not only for the depicting of the difference in speed of adjustment but also allows for measuring this difference. The results of the regression analysis are presented in the table 6 .

The regression analysis shows that there is a significant difference in the speed of adjustment in the case of dividend growth in comparison with a dividend cut. The analysis of the overall sample indicates that speed of adjustment in case of DPS growth is equal to $59.8 \%$ and the speed of adjustment in case of DPS decrease is equal to $64.1 \%$ (sum of betas of lagged variables).

The obtained difference in the speed of adjustment can be explained by the different mechanisms of decision-making in these cases. The majority of investigations argue that a cut in the dividend indicates the financial instability of a firm and becomes a bad signal to the market. That is why in good years managers prefer to smooth the dividend to be sure that the current level of dividends can be possible for future years. So, the payout policy in case of dividends growth has a long planning horizon.

By contrast, the dividend cut can be perceived as the last resort of the firm because in this case the bad signal for the market is unavoidable. In this case, the company solves current problems and the planning horizon becomes shorter, which leads to a decrease in dividend smoothing and a higher speed of adjustment.

It is interesting that a difference in the speed of adjustment to the higher and to the lower dividend levels on the emerging market is significantly higher. It is not surprising that the speed of adjustment in case of dividend cuts is higher in comparison with the values displayed in developed markets. However, the results show that in the case of dividend growth, the dividend smoothing in developing markets is higher.

The results presented above indicate that the speed of adjustment to a higher level of dividends is significantly lower in comparison with the speed of adjustment to a lower level of dividends. So, the third hypothesis can not be rejected.

\section{Lintner model with factor variable}

The third step in the analysis is devoted to a modification of the previous model. Since the model includes the factor variable, the generalized method of moments (GMM) is not applicable. However, this problem will be solved in this case by including factors as a number of dummies. It should be underlined that a standard regression analysis of panel data is not applicable due to the impossibility of using Wooldridge and Pesaran tests with factor variables included. The results obtained are shown in the table 7.

Table 7. Results of regression (model 8)

\begin{tabular}{|c|c|c|c|}
\hline Variables & All countries & Developed & Emerging \\
\hline $\mathrm{DPS}_{\mathrm{it}-1}$ & $-0.642^{* * *}$ & $-0.605^{\star * *}$ & $-0.987^{\star * *}$ \\
\hline $\mathrm{EPS}_{\text {it }}$ & $0.325^{\star \star *}$ & $0.321^{\star * *}$ & $0.359^{* * *}$ \\
\hline
\end{tabular}

Factors (I)

\begin{tabular}{|c|c|c|c|}
\hline 2 & $0.120^{\star * *}$ & $0.108^{\star * *}$ & $0.162^{* * *}$ \\
\hline 3 & $0.113^{\star * *}$ & $0.092^{* * *}$ & $0.167^{\star * *}$ \\
\hline 4 & $0.112^{\star * *}$ & $0.111^{\star * *}$ & $0.159^{* * *}$ \\
\hline 5 & $0.134^{* * *}$ & $0.116^{\star * *}$ & $0.177^{\star * *}$ \\
\hline 6 & $0.115^{\star * *}$ & $0.088^{\star * *}$ & $0.136^{* * *}$ \\
\hline 7 & $0.102^{\star * *}$ & $0.073^{\star * *}$ & $0.232^{\star * *}$ \\
\hline \multicolumn{4}{|c|}{$\mathrm{p}$-values are: ${ }^{* * *} \mathrm{p}<0.01,{ }^{* *} \mathrm{p}<0.05,{ }^{*} \mathrm{p}<0.1$} \\
\hline Tests & \multicolumn{3}{|l|}{ p-values } \\
\hline Sargan & 0.021 & 0.083 & 0.000 \\
\hline \multirow{3}{*}{ Arellano-Bond } & 0.092 & 0.186 & 0.269 \\
\hline & 0.929 & 0.867 & 0.949 \\
\hline & 0.606 & 0.241 & 0.078 \\
\hline
\end{tabular}


Table 8. Results of regression (model 8)

\begin{tabular}{|c|c|c|c|}
\hline Variables & All countries & Developed & Emerging \\
\hline $\mathrm{DPS}_{\mathrm{it}-1}$ & $-0.642^{\star * *}$ & $-0.605^{\star * *}$ & $-0.987^{\star * *}$ \\
\hline $\mathrm{EPS}_{\mathrm{it}}$ & $0.325^{\star \star \star}$ & $0.321^{\star * *}$ & $0.359^{\star * *}$ \\
\hline \multicolumn{4}{|l|}{ Factors (I) } \\
\hline 1 & $-0.112^{\star * \star}$ & $-0.111^{\star \star \star}$ & $-0.161^{\star * *}$ \\
\hline 2 & 0.007 & -0.002 & 0.003 \\
\hline 3 & 0.001 & -0.018 & 0.008 \\
\hline 5 & 0.022 & 0.005 & $0.010^{\star}$ \\
\hline 6 & 0.002 & -0.022 & $-0.017^{\star * *}$ \\
\hline 7 & -0.009 & $-0.038^{\star}$ & $0.076^{* * *}$ \\
\hline
\end{tabular}

Table 9. Results of regression with dummy indicating difference in SOA based on DPS changes

\begin{tabular}{|c|c|c|}
\hline Variables & $\triangle D P S<-25 \%$ & $\triangle D P S \geq-25 \%$ \\
\hline $\mathrm{DPS}_{\mathrm{it}-1}$ & $-1.058^{\star \star \star}$ & $-0.372^{\star \star \star}$ \\
\hline $\mathrm{EPS}_{\mathrm{it}}$ & $0.305^{\star * \star}$ & $0.221^{\star * *}$ \\
\hline \multicolumn{3}{|c|}{$\mathrm{p}$-values are: ${ }^{\star * *} \mathrm{p}<0.01,{ }^{* *} \mathrm{p}<0.05,{ }^{\star} \mathrm{p}<0.1$} \\
\hline Tests & \multicolumn{2}{|c|}{ p-values } \\
\hline Sargan & 0.101 & 0.132 \\
\hline \multirow{3}{*}{ Arellano-Bond } & 0.326 & 0.001 \\
\hline & 0.356 & 0.635 \\
\hline & 0.711 & 0.202 \\
\hline
\end{tabular}

According to the obtained results presented above, there is a significant difference between groups of companies with different DPS changes. However, such model specification allows for comparing groups from second to seventh, but only in the first group. Moreover, the difference between betas in the majority of groups is not so high. That is why it is necessary to change the basic group and compare the betas therein. It is logical to choose the fourth group to be the base group. The results of the GMM with the fourth base group are presented in the table 8. It is not necessary to present Sargan and Arellano - Bond tests, since there are no changes in this part.

As can be seen from the table 9, the results in different groups, excluding the first one, display insignificant differences. By contrast, the speed of adjustment in the first group is significantly higher in comparison with others.

\section{Results of the Lintner model}

The results obtained in the second step indicate that the speed of adjustment in cases of dividend decrease are significantly higher in comparison with the speed of adjustment in cases of dividend growth. During the third step, the sample was divided by groups based on the percentage change of the company's dividend per share in year $t$. However, the results show that only one group has a significant difference compared to others. This group includes observations with the most significant decrease of dividend per share (with fall of DPS less than 25\%). So, at the next step it seems to be logical to compare the speed of adjustment in this group (first group), and to compare all samples with each other (excluding the first group). The results of this analysis are presented in the table 10 . 
Table 10. Results of regression (model 3)

\begin{tabular}{|c|c|c|c|c|}
\hline Variables & Proxy for & All countries & Developed & Emerging \\
\hline Size & Firm maturity & $0.017^{\star \star \star}$ & $0.023^{\star * \star}$ & $0.060^{\star * \star}$ \\
\hline Tang & Assets tangibility & -0.034 & -0.024 & $0.135^{\star}$ \\
\hline $\mathrm{MB}$ & Growth opportunities & 0.001 & 0.014 & 0.013 \\
\hline $\mathrm{SD}(\mathrm{EBIT})$ & Volatility of returns & $-0.001^{\star * *}$ & $-0.004^{* * *}$ & $-0.001^{\star * *}$ \\
\hline SD (PRICE) & Risk & $0.001^{* *}$ & $0.001^{\star *}$ & -0.003 \\
\hline STOCK TURN & Investment horizon & $-0.075^{\star *}$ & $-0.072^{\star *}$ & -0.073 \\
\hline INST OWN & Institutional ownership & $-0.065^{\star}$ & $-0.073^{\star}$ & $0.193^{* *}$ \\
\hline OWN CONC & $\begin{array}{l}\text { Ownership concentra- } \\
\text { tion }\end{array}$ & $0.003^{\star * *}$ & $0.003^{* * *}$ & $0.004^{* * *}$ \\
\hline
\end{tabular}

The results indicate that in case of significant DPS fall, the speed of adjustment is approximately equal to 1 (105.8\%). That means the companies adjust their dividends to target levels very fast and it can be said that there is no dividend smoothing in such cases. The results of another group show a moderate speed of adjustment (37.2\%) and indicate the presence of dividend smoothing.

The difference in speed of adjustment between these two groups can be explained by changes in the planning horizon. As was mentioned in the literature review, a dividend cut is usually perceived as a bad signal by the market. For example, the investigation provided by Grullon et al. in 2002 [1] shows that an increase in dividend level by $10 \%$ is associated with a share price growth of $1.34 \%$ and the decrease in dividend level by $10 \%$ is associated with fall in share prices by $3.71 \%$. Moreover, J. Tirole [13, pp. 311-314) also explains why firms' managers tend to smooth dividends.

To provide an explanation, first we divide the second group into two, with positive and negative changes of dividend per share. In case of positive changes of DPS, firms smooth dividends because of uncertainty in the future level of income. The explanation of such a mechanism was explained in the literature review. In case of a slight decrease in income, companies try to send a positive signal to the market and smooth the dividends (so the cut of dividends is less than decrease of earnings). In both cases the firms have a long planning horizon and consider the future effect of dividend changes.

By contrast, a significant fall in dividends per share (less than 25\%) can be associated with substantial losses of income and crisis in the firm. In such cases, the decision-making process will be based on the current situation in the company and the planning horizon will be lower. Moreover, the crisis in the firm can be obvious to the markets, and maintenance of the DPS level may be argued as being an inefficient payout policy.

\section{Determinants of speed of adjustment}

As was explained our model specification evaluation, the last step in the analysis will be devoted to a determination of parameters affecting the speed of adjustment. To provide this analysis, a two-stage approach should be realized. During the first stage, the vector of speed of adjustment ( $\mathrm{SOA}_{\mathrm{i}}$ ) for each company was obtained. The next step will be devoted to a determination of parameters' significance. Since the first regression is built for each company by years, during the second stage panel regression analysis is not applicable. So, impact on the speed of adjustment is investigated with OLS regression. The results of the analysis are presented in the table 10 .

As can be seen from the table 10, all variables (excluding risk measure) have anticipated signs. The proxy for growth opportunities was the only one insignificant variable in the regressions. However, it should be underlined that the economic significance of volatility of return, risk, and ownership concentration is rather low, due to relatively low betas.

An overall appraisal of the determinants of the speed of adjustment confirms the negative influence of information asymmetry. Firms' size, asset tangibility, institutional ownership, and ownership concentration are all associated with low information asymmetry. The opposite point is true for volatility of returns and the investment horizon. The confirmation of this influence is very important due to the fact that the theory of dividend smoothing is based on information asymmetry [13].

The results presented in this part of the investigation prove that the internal characteristics of firms have a substantial influence on the speed of adjustment in dividend payout decisions. So, the second hypothesis can not be rejected. 


\section{Robustness check}

In this part, we present the results of tests of the regression and the variables. First of all, it should be mentioned that the sample is rather big, so according to the central limit theorem there is no problem with normality. Other potential problems of the model were also tested as will be discussed below.

In the analysis, the Breusch-Pagan / Cook-Weisberg test for heteroskedasticity was applied. According to this test, the hypothesis about constant variance should be rejected, so there is heteroskedasticity in the model. To solve this problem, the White method was used (robust analysis).

To check for functional form misspecification, the Ramsey's specification error test was utilized. The results of the test show that there are no omitted variables and the model is correctly specified.

To control for multicollinearity, the variance inflation factor (VIF) for each variable was calculated. The results obtained are presented in the table 11.

Table 11. VIFs of explanatory variables

\begin{tabular}{|c|c|c|}
\hline Variable & VIF & 1/VIF \\
\hline Size & 1.20 & 0.833110 \\
\hline Tang & 1.04 & 0.958661 \\
\hline $\mathrm{MB}$ & 1.07 & 0.938003 \\
\hline SD (EBIT) & 1.06 & 0.940259 \\
\hline SD (PRICE) & 9.68 & 0.103296 \\
\hline STOCK TURN & 9.75 & 0.102524 \\
\hline INST OWN & 1.19 & 0.837742 \\
\hline OWN CONC & 1.06 & 0.945486 \\
\hline
\end{tabular}

As we can see from this table, VIFs for all variables are less than 10, which means the absence of multicollinearity. Since the generalized method of moments was used in this work, Sargan and Arellano -Bond tests were provided for each regression. The results of these tests are displayed below the results of the regressions' estimation.

\section{Conclusion}

This study is devoted to an analysis of the speed of adjustment in payout policy decisions. We include a systematized review of previous investigations devoted to dividend smoothing. Our research uses an international sample which includes 40 countries and more than 4000 companies. Our findings indicate that dividend smoothing is an international phenomenon. The analysis of the overall sample illustrates an average speed of adjustment equal to $64.8 \%$. It was also found that there is significant difference in speeds of adjustment between different groups.
Our analysis shows that the speed of adjustment in emerging-economy countries is substantially higher than speed of adjustment of those with developed economies. These findings are also confirmed by previous studies. We also underline the difference in speed of adjustment depending on primary economic sector. It was shown that the highest SOA was estimated at the consumer discretionary and the industrial sectors.

The second part of the study analyzes the difference between speed of adjustment towards the lower and the higher dividend levels. Our results indicate that the speed of adjustment in case of dividend decreases is significantly higher.

The results obtained through analysis of the sample, including an analysis on groups depending on percentage changes of dividend per share, revealed that the speed of adjustment in groups with a dividend fall lower than $25 \%$ significantly differs from the whole sample. So, the speed of adjustment in the first group is approximately equal to $100 \%$, and in the whole sample (excluding the first group) the speed of adjustment is equal to $37 \%$. The findings indicate that in case of a significant dividend cut, a company's planning horizon decreases and it adjusts dividend levels to the target level very fast. In other cases, dividend smoothing and long planning horizon is preferable.

Our work also investigates the impact of internal firm characteristics and governance structure on the speed of adjustment. The results show that speed of adjustment is driven by information asymmetry, which was argued for in the majority of previous articles devoted to payout policy.

In consideration of our results and the status of current research in the field, future research on this topic should conceivably be directed towards an investigation into the reasons for the difference in the speed of the adjustment to lower and higher level of dividends.

\section{References}

1. Grullon G., Michaely R., Swaminathan B. Are dividend changes a sign of firm maturity? The Journal of Business. 2002;75(3):387-424. DOI: 10.1086/339889

2. Aivazian V., Booth L., Cleary, S. Do emerging market firms follow different dividend policies from U.S. firms? The Journal of Financial Research. 2003;26(3):371-387. DOI: 10.1111/1475-6803.00064

3. Miller M., Modligliani F. Dividend policy growth and the valuation of shares. The Journal of Business. 1961;34(4):411-433. DOI: 10.1086/294442

4. Andres C., Betzer A., Goergen M., Renneboog L. Dividend policy of German firms: A panel data analysis of partial adjustment models. Journal of Empirical Finance. 2009;16(2):175-187. DOI: 10.1016/j.jempfin.2008.08.002 
5. Lintner J. Distribution of incomes of corporations among dividends, retained earnings, and taxes. The American Economic Review. 1956;46(2):97-113.

6. Brav A., Graham J., Harvey C., Michaely R. Payout policy in the $21^{\text {st }}$ century. Journal of Financial Economics. 2005;77(3):483-527. DOI: 10.1016/j. jifineco.2004.07.004

7. Pirogov N.K., Kravchuk D.V. Lintner model: Example of emerging capital markets. Korporativnye finansy = Journal of Corporate Finance Research. 2011;5(4):511. DOI: $10.17323 /$ j.jcfr.2073-0438.5.4.2011.5-11

8. Lambrecht B., Myers S. A Lintner model of payout and managerial rents. The Journal of Finance. 2012;67(5):1761-1810. DOI: 10.1111/j.15406261.2012.01772.x

9. Guttman I., Kadan O., Kandel E. Dividend stickiness and strategic pooling. The Review of Financial Studies. 2010;23(12):4455-4495. DOI: 10.1093/rfs/hhq096

10. Grullon G., Michaely R. The information content of share repurchase programs. The Journal of Finance. 2004;59(2):651-680. DOI: 10.1111/j.15406261.2004.00645.x

11. Goranova M., Ryan L. Shareholder activism: A multidisciplinary review. Journal of Management. 2014;40(5):1230-1268. DOI: $10.1177 / 0149206313515519$

12. Shah A.S., Noreen U. Stock price volatility and role of dividend policy: Empirical evidence from Pakistan. International Journal of Economics and Financial Issues. 2016;6(2):461-472.

13. Tirole J. The theory of corporate finance. Princeton, NJ: Princeton University Press; 2010. 656 p.

14. Easterbrook F. Two agency-cost explanations of dividends. The American Economic Review. 1984;74(4):650-659.

15. Jensen M. Agency costs of free cash flow, corporate finance, and takeovers. The American Economic Review. 1986;76(2):323-329.

16. Bates T., Kahle K., Stulz R. Why do U.S. firms hold so much more cash than they used to? The Journal of Finance. 2009;64(5):1985-2021. DOI: 10.1111/j.15406261.2009.01492.x

17. DeAngelo H., DeAngelo L. Capital structure, payout policy, and financial flexibility. SSRN Electronic Journal. 2007;(Oct). DOI: 10.2139/ssrn.916093

18. Brennan M.J., Thakor A.V. Shareholder preferences and dividend policy. The Journal of Finance. 1990;45(4):993-1018. DOI: 10.1111/j.1540-6261.1990. tb02424.x
19. Berk J., DeMarzo P. Corporate finance. Boston: Pearson/Addison Wesley; 2007. 988 p.

20. Skinner D. The evolving relation between earnings, dividends and stock repurchases. Journal of Financial Economics. 2008;87(3):582-609. DOI: 10.1016/j. jifineco.2007.05.003

21. Baker M., Ruback R., Wurgler J. Behavioral corporate finance. In: Constantinides G., Harris M., Stulz R. Handbook of the economics of finance. Amsterdam: Elsevier; 2007:145-186.

22. Fama E., French K. Disappearing dividends: Changing firm characteristics or lower propensity to pay? Journal of Financial Economics. 2001;60(1):3-43. DOI: $10.1016 /$ S0304-405X(01)00038-1

23. Eije H. von, Megginson W. Dividends and share repurchases in the European Union. Journal of Financial Economics. 2008;89(2):347-374. DOI: 10.1016/j.jfineco.2007.11.002

24. Jeong J. Determinants of dividend smoothing in emerging market: The case of Korea. Emerging Markets Review. 2013;17:76-88. DOI: 10.1016/j. ememar.2013.08.007

25. Leary M., Michaely R. Determinants of dividend smoothing: Empirical evidence. The Review of Financial Studies. 2011;24(10):3197-3249. DOI: 10.1093/rfs/hhr072

26. Allen F., Bernardo A., Welch I. A theory of dividends based on tax clienteles. The Journal of Finance. 2000;55(6):2499-2536. DOI: 10.1111/00221082.00298

27. McNulty T., Nordberg D. Ownership, activism and engagement: Institutional investors as active owners. Corporate Governance: An International Review. 2016;24(3):346-358. DOI: 10.1111/corg.12143

28. Javakhadze D., Ferris S.P., Sen N. An international analysis of dividend smoothing. Journal of Corporate Finance. 2014;29:200-220. DOI: 10.1016/j. jcorpfin.2014.09.007

29. Larkin Y., Leary M.T., Michaely R. Do investors value dividend-smoothing stocks differently? Management Science. 2017;63(12):3999-4446. DOI: 10.1287/ mnsc.2016.2551

30. Arellano M., Bond S. Some tests of specification for panel data: Monte Carlo evidence and an application to employment equations. The Review of Economic Studies. 1991;58(2):277-297. DOI: 10.2307/2297968 


\section{Appendices}

Table 12. Determinants of speed of adjustment in previous investigations

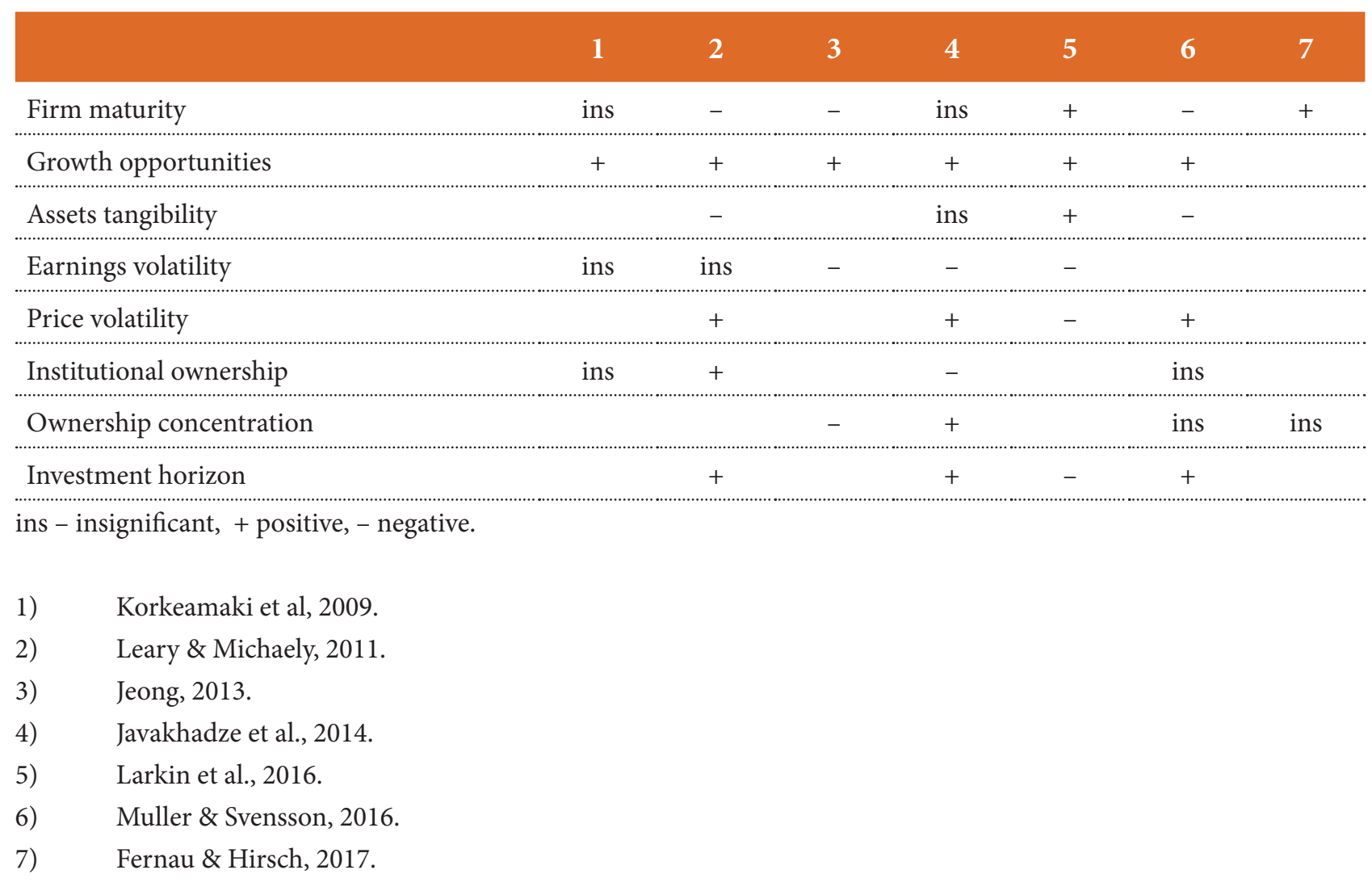

Table 13. Sample selection (Geographical description)

\begin{tabular}{|c|c|c|c|}
\hline Country & Number of firms & Percentage & Cumulative \\
\hline Australia & 109 & 2.56 & 2.56 \\
\hline Belgium & 14 & 0.33 & 2.89 \\
\hline Bermuda & 90 & 2.11 & 5 \\
\hline Brazil & 17 & 0.4 & 5.4 \\
\hline Canada & 140 & 3.29 & 8.68 \\
\hline Cayman Islands & 37 & 0.87 & 9.55 \\
\hline Channel Islands & 9 & 0.21 & 9.76 \\
\hline Chili & 27 & 0.63 & 10.4 \\
\hline China & 177 & 4.15 & 14.55 \\
\hline Denmark & 14 & 0.33 & 14.88 \\
\hline Finland & 34 & 0.8 & 15.68 \\
\hline France & 99 & 2.32 & 18 \\
\hline Germany & 37 & 0.87 & 18.87 \\
\hline Hong Kong & 58 & 1.36 & 20.23 \\
\hline India & 201 & 4.72 & 24.95 \\
\hline
\end{tabular}




\begin{tabular}{|c|c|c|c|}
\hline Country & Number of firms & Percentage & Cumulative \\
\hline Indonesia & 25 & 0.59 & 25.53 \\
\hline Ireland & 14 & 0.33 & 25.86 \\
\hline Israel & 30 & 0.7 & 26.57 \\
\hline Japan & 1373 & 32.22 & 58.79 \\
\hline Malaysia & 162 & 3.8 & 62.59 \\
\hline Mexico & 6 & 0.14 & 62.73 \\
\hline Netherlands & 22 & 0.52 & 63.25 \\
\hline New Zealand & 34 & 0.8 & 64.05 \\
\hline Nigeria & 5 & 0.12 & 64.16 \\
\hline Norway & 11 & 0.26 & 64.42 \\
\hline Philippines & 20 & 0.47 & 64.89 \\
\hline Poland & 8 & 0.19 & 65.08 \\
\hline Saudi Arabia & 5 & 0.12 & 65.2 \\
\hline Singapore & 90 & 2.11 & 67.31 \\
\hline South Africa & 56 & 1.31 & 68.62 \\
\hline South Korea & 100 & 2.35 & 70.97 \\
\hline Spain & 28 & 0.66 & 71.63 \\
\hline Sri Lanka & 34 & 0.8 & 72.42 \\
\hline Sweden & 48 & 1.13 & 73.55 \\
\hline Switzerland & 56 & 1.31 & 74.87 \\
\hline Taiwan & 135 & 3.17 & 78.03 \\
\hline Thailand & 126 & 2.96 & 80.99 \\
\hline Turkey & 5 & 0.12 & 81.11 \\
\hline United Kingdom & 216 & 5.07 & 86.18 \\
\hline United States & 589 & 13.82 & 100 \\
\hline
\end{tabular}

Table 14. Correlation matrix

\begin{tabular}{|c|c|c|c|c|c|c|c|}
\hline & size & $\operatorname{tang}$ & MB & SD (EBIT) & SD (PRICE) & STOCK TURN & INST OWN \\
\hline size & 1 & & & & & & \\
\hline tang & 0.129 & 1 & & & & & \\
\hline $\mathrm{MB}$ & -0.0847 & -0.0789 & 1 & & & & \\
\hline $\mathrm{SD}(\mathrm{EBIT})$ & 0.2544 & 0.0652 & -0.0547 & 1 & & & \\
\hline SD (PRICE) & 0.0209 & -0.0121 & 0.038 & -0.0042 & 1 & & \\
\hline STOCK TURN & 0.1114 & 0.0116 & 0.0207 & 0.021 & 0.9444 & 1 & \\
\hline INST OWN & 0.3737 & 0.0716 & 0.0304 & 0.0478 & -0.0079 & 0.1275 & 1 \\
\hline OWN CONC & -0.2553 & -0.0656 & -0.0205 & -0.083 & -0.0068 & -0.0395 & -0.2755 \\
\hline
\end{tabular}

